\title{
Chłonkotok u pacjentów z wrodzonymi wadami serca w przebiegu leczenia kardiologicznego i kardiochirurgicznego
}

\author{
Lymphorrhea in patients with congenital heart defects \\ during cardiac drug therapy or cardiac surgery
}

\author{
Anna Romanowicz ${ }^{1}$, Andrzej Sołtyszewski ${ }^{2}$, Ireneusz Haponiuk ${ }^{1,3}$, Maciej Chojnicki ${ }^{1}$, \\ Mariusz Steffens ${ }^{1}$, Konrad Paczkowski ${ }^{1}$ \\ ${ }^{1}$ Oddział Kardiochirurgii Dziecięcej, Szpital Św. Wojciecha, COPERNICUS w Gdańsku \\ ${ }^{2}$ Oddział Chirurgii Ogólnej, Szpital Św. Wojciecha, COPERNICUS w Gdańsku \\ ${ }^{3}$ Katedra Fizjoterapii, Wydział Rehabilitacji i Kinezjologii, Akademia Wychowania Fizycznego i Sportu w Gdańsku
}

\section{Streszczenie}

Chłonkotok jest rzadkim, lecz bardzo poważnym powikłaniem rozległych zabiegów operacyjnych w obrębie klatki piersiowej (operacje wrodzonych wad serca), jak również wrodzonym problemem noworodków, lub konsekwencją procesów rozrostowych w obrębie klatki piersiowej. Przedstawiamy przyczyny chłonkotoku, postępowanie diagnostyczne oraz możliwości terapeutyczne farmakologiczne oraz operacyjne.

Słowa kluczowe: chłonkotok, wrodzona wada serca, kardiochirurgia dziecięca

Folia Cardiologica 2018; 13, 4: 359-366

\section{Budowa i funkcja układu chłonnego}

Krążenie płynów ustrojowych w organizmie człowieka jest możliwe dzięki wzajemnie uzupełniającym się funkcjom zarówno układu limfatycznego (chłonnego), jak również układu krwionośnego. Odkrywcą systemu limfatycznego u ludzi był duński naukowiec Thomas Bartholin żyjący w XVII wieku, aczkolwiek na przestrzeni kolejnych stuleci wielu uczonych pogłębiało wiedzę na temat budowy i znaczenia tego układu. Naczynia limfatyczne odgrywają bardzo istotną rolę $w$ procesach reabsorpcji płynów oraz białek z przestrzeni śródmiąższowej do układu krążenia, absorpcji lipidów z jelita i transportu długołańcuchowych triglicerydów oraz substancji lipofilnych do krążenia wrotnego, a większych cząsteczek do naczyń limfatycznych kosmków jelita cienkiego. Wpływają ponadto na transport antygenów, komórek dendrytycznych i limfocytów, które przedostały się z tkanek do ich światła inicjując pierwotną odpowiedź immunologiczną poprzez prezentację antygenów limfocytom T i B. Naczynia limfatyczne transportują również komórki z ognisk nowotworzenia oraz rozprzestrzenianie się komórek z ognisk zapalenia. Ostatnie badania dowiodły, że oddziaływują również na utrzymanie homeostazy kwasu hialuronowego, stale transportując go przez naczynia chłonne i degradując w węzłach oraz poza układem limfatycznym [1-5].

W warunkach fizjologicznych układ krążenia doprowadza do tkanek składniki odżywcze i tlen, zabierając zbędne produkty przemiany metabolizmu komórkowego. Podczas krążenia krwi pewna ilość płynu z osocza przedostaje się do tkanek, z których z powrotem dostaje się do układu krążenia za pomocą systemu naczyń chłonnych.

Adres do korespondencji: lek. Konrad Paczkowski, oddział Kardiochirurgii Dziecięcej, Szpital Św. Wojciecha COPERNICUS, AI. Jana Pawła II 50, 80-462 Gdańsk, e-mail: konradpaczkowski@gmail.com 
Poza centralnym układem nerwowym, szpikiem kostnym i tkankami nieunaczynionych, takimi jak np. chrząstka, rogówka i naskórek, znajdują się ślepo zakończone naczynia limfatyczne, które zbierają przesączony płyn. Zdecydowana większość płynu śródtkankowego (ok. 90\%) zbierana przez limfatyczne kapilary jest transportowana naczyniami zbiorczymi, a następnie przewodami limfatycznymi do tzw. kąta żylnego - miejsca połączenia przewodu piersiowego z systemem żylnym. Kąt żylny jest ujściem żyły szyjnej wewnętrznej do żyły podobojczykowej lewej. Pozostała część chłonki spływa do przewodu limfatycznego uchodzącego do prawego kąta żylnego - to jest miejsca połączenia żyły szyjnej z żyłą podobojczykową prawą. Inne dodatkowe połączenia układu limfatycznego z żylnym znajdują się w żyłach: nerkowej, wątrobowej i nadnerczowej oraz w innych umiejscowieniach obwodowych. Podczas transportu przez naczynia limfatyczne chłonka wraz z wynaczynionymi leukocytami jest filtrowana przez lokalne węzły chłonne, skąd następnie jest transportowana do krwi [1, 3].

Naczynia limfatyczne włosowate są cienkościenne, o średnicy nieco większej niż włosowate naczynia krwionośne (tj. w granicach 10-60 $\mu \mathrm{m}$ ). Natomiast dojrzałe włosowate naczynia chłonne są sfałdowane, zbudowane z pojedynczej warstwy komórek śródbłonka, nie mają błony podstawnej, lub jest ona nieciagła. Komórki śródbłonka naczyń limfatycznych zazębiają się wzajemnie swymi wypustkami, tworząc typowe połączenia międzykomórkowe, wnikają w siebie i łączą się małymi i nieciągłymi połączeniami. Gradient ciśnień łatwo otwiera połączenia, dzięki czemu płyn znajdujący się śródtkankowo może bardzo szybko przenikać z przestrzeni pozakomórkowej do naczynia chłonnego $[5,6]$. Limfatyczne naczynia włosowate nie mają właściwości kurczenia się, a przepływ chłonki jest w nich możliwy głównie dzięki ruchom otaczających je mięśni szkieletowych, pulsacji otaczających tętnic oraz stymulacji wywoływanej ruchami oddechowymi [4-6].

Większe naczynia chłonne - tzw. naczynia zbiorcze, zawierają warstwę miocytów gładkich, błonę podstawną i zastawki. Dzięki temu posiadają zdolność kurczenia się, a obecne w nich zastawki zapobiegają ruchowi wstecznemu chłonki. Ponadto, zasadniczo, w naczyniach zbiorczych połączenia między komórkami śródbłonka mają charakter ciągły. Zarówno w naczyniach limfatycznych włosowatych, jak i w naczyniach zbiorczych, występują białka połączeń międzykomórkowych: VE-kadheryna, zonulina, okludyna i klaudyna $[4,5,6]$.

Anatomicznie przewód piersiowy zaczyna się zbiornikiem mleczu w jamie brzusznej na wysokości Th11-Th12 i dzieli się na trzy odcinki: brzuszny, piersiowy i szyjny. Przewód piersiowy z jamy brzusznej przechodzi poprzez rozwór aorty na wysokości Th10-Th12, przez przeponę do jamy klatki piersiowej, gdzie dzieli się na dwa lub więcej pni, które następnie ponownie łączą się ze sobą. Na wysokości kręgów Th5-Th7 przewód piersiowy przechodzi z prawej do lewej połowy klatki piersiowej, gdzie biegnie po prawej stronie aorty zstępującej i osiąga łuk aorty na wysokości odejścia lewego wstecznego nerwu krtaniowego. Powyżej łuku aorty przewód piersiowy przebiega przyśrodkowo od tętnicy podobojczykowej, i uchodzi do lewego kąta żylnego położonego ok. $4 \mathrm{~cm}$ od obojczyka. Część szyjna przewodu piersiowego zbiera chłonkę z głowy, szyi, kończyn górnych, płuc, oskrzeli oraz śródpiersia. W okolicy szyi przewód piersiowy położony jest na mięśniach długich kręgosłupa. Wyłącznie w wyjątkowych przypadkach przewód piersiowy może uchodzić do prawego kąta żylnego, ale tylko, gdy prawa tętnica podobojczykowa odchodzi jako ostatnia gałąź łuku aorty. Należy jednak zaznaczyć, że istnieje duża anatomiczna zmienność osobnicza nawet do 25-33\% populacji, u której może występować albo kilka przewodów piersiowych i/lub nietypowe połączenia z żyłą bezimienną, z żyłami międzyżebrowymi bądź żyłami lędźwiowymi. W przeciwieństwie do włosowatych naczyń limfatycznych, przewód piersiowy ma dobrze rozwiniętą błonę podstawną i zbudowany jest z trzech warstw: przydanki, warstwy mięśni gładkich oraz błony wewnętrznej, a na całym swoim przebiegu posiada zastawki podobne do zastawek żylnych. W ścianie przewodu występuje układ włókien sprężystych o przebiegu okrężnym, promienistym, podłużnym i niekiedy drabiniastym, co ułatwia przepływ i drenaż chłonki do naczyń żylnych [4-6].

$\mathrm{U}$ dorosłego człowieka w ciągu doby wytwarza się około 2 I chłonki, która trafia do układu krążenia poprzez przewód piersiowy, powstały z połączenia naczyń chłonnych w jamie brzusznej. Przez przewód piersiowy w ciągu godziny transportowane jest ok. 60-190 ml chłonki (średnio 1,38 ml/ /kg m.c./godz. - w zależności od spożycia pokarmu), co w ciągu doby stanowi $2500-4000 \mathrm{ml}$ mleczu, z czego $45 \%$ pochodzi z wchłaniania jelitowego, 35\% - dwunastniczego i ok. 20-30\% - z wątroby. Zasadniczą rolą przewodu piersiowego jest transport do układu żylnego tłuszczów, które zostały wchłonięte z przewodu pokarmowego. Kwasy tłuszczowe o krótkim łańcuchu węglowym w postaci zawiesiny micelarnej są bezpośrednio absorbowane z jelitowych naczyń chłonnych do systemu żyły wrotnej. Natomiast czas, jaki upływa od spożycia pokarmu do pojawienia się tłuszczów w naczyniach systemu żylnego, wynosi kilkadziesiąt minut (zwykle nie przekracza 1 godziny), a szczyt wchłaniania obserwuje się po ok. 6 godzin po jedzeniu $[3,7,8]$.

\section{Rozwój układu chłonnego}

Układ chłonny człowieka powstaje już we wczesnym etapie rozwoju podczas życia płodowego. Początek rozwoju układu chłonnego przypada na 5 tydzień życia płodowego. Powstają wówczas szczeliny między komórkami mezenchymalnymi, które się łączą, a komórki je wyściełające różnicują się w kierunku komórek śródbłonka. Z połączenia szczelin powstaja pierwotne naczynia limfatyczne, tworzące rozgałęzioną sieć; 
miejscowe poszerzenia naczyń tworzą worki limfatyczne. W 8. tygodniu życia płodowego jest ich sześć: parzyste worki szyjne, w okolicy połączenia żyły podobojczykowej z żyłami sercowymi przednimi, parzyste worki biodrowe blisko połączenia żył biodrowych z żyłami sercowymi tylnymi, worek zaotrzewnowy w miejscu przyczepu krezki do ściany tylnej brzucha oraz zbiornik mleczu, leżący grzbietowo względem worka zaotrzewnowego na wysokości gruczołów nadnerczowych. Naczynia limfatyczne odchodzące od worków limfatycznych towarzyszą dużym naczyniom żylnym. Około 9. tygodnia ciąży stwierdza się u płodu obecność zbiornika mleczu, przewodu piersiowego i naczynia chłonne biegnące w korzeniu krezki. Zbiornik mleczu jest połączony z workami szyjnymi prawym i lewym przewodem piersiowym; między nimi wytwarzają się liczne anastomozy. Przewód piersiowy ostateczny powstaje z dystalnej części przewodu piersiowego prawego, naczyń łączących i proksymalnej części lewego przewodu piersiowego prawego. Około 3 miesiąca życia płodowego, w ciągu dalszego rozwoju układu limfatycznego, powstają pierwsze węzły chłonne z przekształconych worków limfatycznych, komórki mezenchymalne naciekają worki limfatyczne, a worki limfatyczne rozdzielają się na przewody i zatoki. Węzły chłonne powstają z mezenchymy i tworzą się również jako elementy towarzyszące naczyniom limfatycznym wzdłuż ich przebiegu [5].

\section{Przyczyny chłonkotoku}

Przyczyną chłonkotoku jest brak drożności lub przerwanie ciągłości naczyń chłonnych na każdym odcinku. Spośród wielu przyczyny mogą być upośledzonego drenażu chłonki należy wyróżnić:

- wady rozwojowe (np. hipoplazja bądź aplazja przewodu piersiowego) oraz malformacje limfatyczne

- nowotwory i guzy śródpiersia (najczęściej chłoniaki)

- jatrogenne uszkodzenie przewodu piersiowego, czyli powikłania po operacjach zwłaszcza w zakresie chirurgii klatki piersiowej (operacje przełyku) i kardiochirurgii (leczenie wad wrodzonych i nabytych serca)

- jatrogenne uszkodzenie przewodu piersiowego po operacjach szyi - częstość jego występowania jest niska i wynosi ok. 1-3\%, przy czym w większości przypadków występuje on po lewej stronie, co jest spowodowane w 75-92\% przypadków ujściem przewodu po stronie lewej. Ryzyko wystąpienia tego powikłania wzrasta wraz z rozległością zabiegu i najczęściej dotyczy całkowitej tyroidektomii z preparowaniem kompartmentów bocznych wynosi 4,5-8,3\%, podczas gdy tyroidektomia z preparowaniem kompartmentu centralnego wynosi zaledwie 0,8-1,4\% [3, 9].

- penetrujące urazy klatki piersiowej.

- niewydolność serca jako wynik dysfunkcji skurczowej na podłożu wielu czynników w tym zapalenia mięśnia sercowego spowodowanego infekcją wirusową.
- leczenie i postępowanie interwencyjne - np. cewnikowanie żyły głównej górnej [10].

- wrodzony chłonkotok - jego rozwój może mieć miejsce jeszcze w okresie życia płodowego, wówczas obecność dużej ilości chłonki w jamach ciała może powoduje ucisk zarówno na naczynia krwionośne jak i narządy, prowadząc do istotnego obniżenia powrotu żylnego, rzutu serca i przepływu krwi przez nerki. W konsekwencji przedostawanie się płynów i białka do tkanek skutkuje uogólnionym obrzękiem płodu, który stanowi zagrożenie życia płodu, zwłaszcza jeśli pojawi się przed 24. tygodniem ciąży. Jednak wrodzony chłonkotok opłucnowy jest rzadką przyczyną uogólnionego obrzęku płodu o podłożu nieimmunologicznym - stanowi ok $5 \%$ przypadków [11, 12, 13].

- inne schorzenia ogólnoustrojowe np. limfangioleiomiomatoza, amyloidoza.

Chłonkotok powstaje na skutek zaburzenia prawidłowego spływu chłonki do układu żylnego doprowadzając do jej zastoju w naczyniach, a w konsekwencji do przełamania układu zastawkowego obwodowych naczyń chłonnych, ich przepełnienia i znacznego poszerzenia. Wówczas spływ chłonki do krążenia żylnego odbywa się obocznymi naczyniami chłonnymi, a skrajne przeciążenie naczyń chłonnych prowadzi do przedostawania się chłonki do tkanek, i następnie do jam: opłucnej, jamy otrzewnej lub osierdzia.

\section{Chłonka}

Chłonka jest płynem niejednorodnym o ciężarze właściwym 1,012-1,025 i pH 7,4-7,8. Makroskopowo ma wygląd gęstego mleka i jest bezwonna. W jej skład wchodzą zarówno elementy upostaciowane, jak i rozpuszczalne. Do elementów upostaciowanych chłonki zalicza się: komórki krwi, limocyty, wśród których > 90\% to limfocyty T oraz czerwone ciałka krwi. Natomiast głównym składnikiem chłonki są tłuszcze występujące w ilości 14-210 mmol/I ( tłuszcz obojętny, wolne kwasy tłuszczowe, sfingomieliny, fosfolipidy oraz cholesterol i jego estry) [5, 13].

Zdecydowanie największa część chłonki w organizmie człowieka pochodzi z przestrzeni międzykomórkowych jelita i wątroby. Długołańcuchowe triglicerydy pochodzące ze strawionego $\mathrm{w}$ jelicie tłuszczu są redukowane do monoglicerydów i kwasów tłuszczowych, które następnie pod postacią chylomikronów transportowane są systemem chłonnym. Chylomikrony są odpowiedzialne za zmętnienie chłonki i nadają jej białawe zabarwienie. W skład chłonki oprócz chylomikronów wchodzą białka, także inne cząsteczki, całe komórki, niekiedy również bakterie. W warunkach fizjologicznych chłonka jest transportowana siecią drobnych naczyń chłonnych do węzłów chłonnych, gdzie ulega oczyszczeniu, a następnie spływa do położonego do przodu od trzonów pierwszych kręgów lędźwiowych zbiornika mleczu. Następnie płynie poprzez 
przewód piersiowy położony w tylnym śródpiersiu po stronie prawej i ostatecznie uchodzi do układu żylnego na poziomie spływu żył szyjnych i żyły podobojczykowej po stronie lewej.

\section{Objawy chłonkotoku}

Objawy zależą przede wszystkim od wieku pacjenta, przyczyny chłonkotoku oraz szybkości jego narastania. U większości noworodków z chłonkotokiem opłucnowym już w badaniach prenatalnych stwierdza się nieprawidłowości. Po urodzeniu noworodek może być obrzękły, z towarzyszącymi objawami niewydolności serca i niewydolności oddechowej. Ponadto w przypadku hipoplazji płuc, będącej następstwem ucisku przez płyn, niewydolność ta może się okazać szczególnie ciężka. W badaniu fizykalnym noworodka z chłonkotokiem opłucnowym stwierdza się znaczne ściszenie szmerów oddechowych i tonów serca. U noworodków z chłonkotokiem brzusznym poszerzony jest obwód brzucha, u chłopców także moszny. Bardzo rzadko chłonkotok brzuszny może doprowadzić do niewydolności oddechowej. Reasumując, ciężkość objawów chłonkotoku u noworodka zależy od umiejscowienia oraz ilości płynu i waha się od zagrażających życiu objawów ciężkiej niewydolności oddechowej lub tamponady serca, aż do całkowitego braku objawów klinicznych [1, 2].

Dorosły pacjent zazwyczaj odczuwa duszność z towarzyszącym tachypnoe. W badaniu fizykalnym można stwierdzić ściszenie lub zniesienie szmeru oddechowego, skrócenie odgłosu wypukowego oraz zniesienie drżenia głosowego. Uszkodzenie przewodu piersiowego z następowym masywnym chłonkotokiem może prowadzić do zaburzeń elektrolitowych pod postacią hiponatremii, do wstrząsu hipowolemicznego ale również do uogólnionych obrzęków $[1,2,12]$. Stały wyciek limfy w okolicę pooperacyjną skutkuje miejscowymi powikłaniami jak opóźnione gojenie rany bądź martwica płata skórnego. Niestety, utrata limfy może doprowadzić również do poważnych konsekwencji stanu odżywienia pacjenta w postaci zaburzeń metabolicznych. Ponadto, leukopenia i obniżona odporność zwiększają ryzyko poważnych infekcji w tym rozwinięcia uogólnionej reakcji zapalnej [2]. Wszystkie te powikłania mogą w konsekwencji spowodować znaczne wydłużenie hospitalizacji, a także wzrost chorobowości i śmiertelności wśród pacjentów.

\section{Diagnostyka i rozpoznanie chłonkotoku}

Obecność płynu w jamach ciała można wykazać różnymi technikami obrazowania, takimi jak badanie radiologiczne (RTG), ultrasonografia (USG) lub tomografia komputerowa (CT). Jednak ze względu na dużą dostępność, łatwość wykonania (nawet przyłóżkowo w przypadku ciężkiego stanu pacjenta) oraz niewielką szkodliwość uważa się USG za metodę z wyboru. Z uwagi na fakt, że przez przewód piersiowy przepływa około 4 litrów płynu na dobę, zwykle w przypadku jego niedrożności (niezależnie od przyczyny) stwierdza się dużą ilość płynu w jamie opłucnowej [1, 9, 13, 14].

Następnym etapem jest nakłucie opłucnej, w trakcie którego uzyskuje się mleczny płyn do badania laboratoryjnego. W zależności od ilości płynu pozostawia się dren w jamie opłucnowej w celu leczenia wykorzystując metodę drenażu opłucnowego.

Proces diagnostyczny wieńczy badanie laboratoryjne pobranego płynu, w którym oznaczona zostaje duża zawartość trójglicerydów i chylomikronów, zwłaszcza gdy stężenie trójglicerydów w badanym płynie przekracza 110 mg/dl - wówczas z 99\% pewnością mamy chłonkotok. W przypadkach z mniejszym stężeniem decydujące znaczenia ma obecność chylomikronów.

Za rozpoznaniem chłonkotoku w badaniach laboratoryjnych uzyskanego płynu przemawiają:

- obecność kuleczek tłuszczu w badaniu mikroskopowym;

- większe stężenie tłuszczów w płynie niż w surowicy;

- mniejsze o połowę stężenia białka całkowitego w płynie niż w surowicy;

- większe stężenie trójglicerydów w płynie niż w surowicy;

- wskaźnik cholesterol/trójglicerydy, czyli stosunek stężeń cholesterolu do trójglicerydów jeśli jest mniejszy niż 1,0 świadczy, że płynem wysiękowym jest chłonka;

- stężenie trójglicerydów > 1,24 mmol/I w prawie 100\% świadczy o tym, że płyn jest chłonką;

- stężenie trójglicerydów < 0,56 mmol/I prawie w 95\% przemawia za tym, że płyn nie jest chłonką;

- stężenie triglicerydów > 1,2 mmol/l (lub 200 mg/dl);

- stężenie białka ponad 2,5 g/dl,

- aktywność dehydrogenazy mleczanowej większa niż $110 \mathrm{IU} / \mathrm{I}$

- liczba komórek przekraczająca 1000/ml, z dominacją limfocytów.

Rozpoznanie chłonkotoku u płodu opiera się głównie na badaniu ultrasonograficznym, aby jednak prenatalnie potwierdzić wstępne rozpoznanie, należy wykazać, że zgromadzony w klatce piersiowej bądź jamie brzusznej płyn jest chłonką. W tym celu można wykorzystać oznaczenie stężenia immunoglobulin klasy G (IgG) w pobranym płynie i porównać go ze stężeniem oznaczonym w osoczu płodu. Jeśli zawiera on więcej immunoglobulin niż osocze stanowi to potwierdzenie chłonkotoku. Natomiast w przypadku płynu w klatce piersiowej, w obrazie ultrasonograficznym płodu, można w łatwy sposób uwidocznić istotnie podwyższone ciśnienie w klatce piersiowej przedstawione jako odwrócenie krzywizny kopuł przepony do jamy brzusznej lub poprzez bezpośredni pomiar płynu w jamie klatki piersiowej.

Podobnie w przypadku dzieci i dorosłych zazwyczaj badanie USG jest wystarczające do wysunięcia podejrzenia chłonkotoku, a punkcja i oznaczenia biochemiczne stanowią podstawę rozpoznania. W niektórych przypadkach 
stosowana jest limfografia bezpośrednia bądź z wykorzystaniem tomografii komputerowej, te metody są zazwyczaj stosowane u dorosłych lub w wyjątkowo wątpliwych sytuacjach w przypadku dzieci i noworodków.

Podsumowując, limfografii metodą tomografii komputerowej lub uwidacznianie naczyń chłonnych w poprzecznych i wielopłaszczyznowych projekcjach z rekonstrukcją obrazów uzyskanych w tomografii wielorzędowej nie wykonuje się rutynowo u noworodków i małych dzieci. Natomiast limfografia bezpośrednia zdecydowanie częściej bywa wykorzystywana w przypadku niemowlęt i małych dzieci. Polega na podaniu do węzła chłonnego pachwinowego 0,5-4,5 ml oleistego środka kontrastowego a następnie próbie uwidocznienia naczyń chłonnych i zobrazowania zatkanego przewodu piersiowego, refluksu lub nawet miejsca wycieku chłonki. Tymczasem limfografia rezonansu magnetycznego umożliwia precyzyjne obrazowanie naczyń chłonnych bez użycia środków kontrastowych, a scyntygrafia układu chłonnego z wysoką rozdzielczością obrazuje obwodowe naczynia chłonne i pozwala na ocenę dynamiki przepływu chłonki nawet u małych niemowląt i noworodków [13, 14].

U dorosłych pacjentów można dodatkowo przeprowadzić biologiczną próbę barwnikową polegającą na podaniu do wypicia ok. $150 \mathrm{ml}$ gęstej śmietany zmieszanej z fioletem gencjany lub błękitem metylenowym i obecność barwnika w płynie będzie przemawiać za uszkodzeniem przewodu piersiowego.

Diagnostyka i rozpoznanie wrodzonego chłonkotoku opłucnowego powinno być rozszerzone o badania dodatkowe umożliwiające potwierdzenie bądź wykluczenie obecności w tkankach miękkich i trzewiach malformacji limfatycznych. Wrodzony chłonkotok ponadto obliguje lekarza do poszukiwania cech i objawów zespołów chorobowych, w których istotnym elementem są zaburzenia dotyczące układu chłonnego takich jak zespół Hennekama, zespół Aagenaesa, zespół obrzęk limfatyczny-podwójny rząd rzęs, zespół CLAPO, zespół ODELAID, zespół Turnera [2, 11, 12].

U większości chorych rozpoznanie chłonkotoku następuje w oparciu o podstawowe badania obrazowe, szybko dochodzi do samoistnego ustąpienia chłonkotoku, więc jeśli nie skłania do tego szczególnie ciężki obraz kliniczny, nie ma wskazań do wykonywania dalszych badań obrazowych mających na celu zlokalizowanie miejsca wycieku chłonki. Natomiast w sytuacji długo utrzymującego się chłonkotoku, przed podjęciem decyzji o rodzaju interwencji należy zidentyfikować miejsce wycieku chłonki.

\section{Leczenie chłonkotoku}

Przedstawiając ogólny zarys leczenia chłonko toku, jest on przede wszystkim ukierunkowany na leczenie choroby podstawowej, która jest przyczyną wysięku, oraz na usunięcie mechanicznych konsekwencji zbiornika płynowego w jamie opłucnowej. Istnieją dwa zasadnicze sposoby leczenia chłonkotoku:

- leczenie zachowawcze - drenaż opłucnowy oraz całkowite żywienie pozajelitowe, dieta ubogotłuszczowa, i somatostatyna lub jej analogi,

- leczenie operacyjne - leczenie chirurgiczne.

Stosunkowo często stosuje się kombinację tych metod, ponieważ leczenie zachowawcze może być wstępem do leczenia operacyjnego, albo kontynuacją po leczeniu operacyjnym. Należy pamiętać, że w około 50\% przypadków dochodzi do samoistnego zamknięcia się przewodu piersiowego, dlatego uwzględniając ilość płynu oraz stan kliniczny pacjenta, warto rozpocząć terapię właśnie od leczenia zachowawczego. Wyniki zachowawczego leczenia chłonkotoku są uzależnione od szeregu czynników, spośród których do najważniejszych należą wielkość wycieku i sposób jego leczenia. Zwykle wystarcza 14 dni intensywnej terapii zachowawczej do zahamowania wycieku chłonki. Po jej ustąpieniu (drenaż dobowy z jamy opłucnej < $50 \mathrm{ml} /$ dobę) przed usunięciem drenów zaleca się wykonanie próby posiłkowej. Choremu podaje się do wypicia wysokotłuszczowy pokarm. Oczywiście w przypadkach występowania dużej lub szybko narastającej ilości płynu, konieczne są zabiegi chirurgiczne. W okresie zdrowienia konieczne jest całkowite żywienie pozajelitowe, które zmniejsza produkcję chłonki, lub stosowanie doustnej diety ubogotłuszczowej z suplementacją średniołańcuchowych kwasów tłuszczowych $[11,12,13]$. Natomiast w przypadkach urazowego uszkodzenia przewodu piersiowego konieczna okazać się może interwencja torakochirurgiczna, a w przypadkach chłonkotoku w przebiegu procesu nowotworowego - radioterapia.

Płody z chłonkotokiem, których stan jest stabilny, mogą być objęte wyłącznie wewnątrzmacicznym leczeniem zachowawczym i obserwacją. Jednak w przypadku wystąpienia obrzęku uogólnionego lub nasilającej się niewydolności sercowo-naczyniowej konieczna jest intensyfikacja leczenia. W takich przypadkach należy w jak najszybszym czasie przeprowadzić skuteczny drenaż płynu z klatki piersiowej do owodni płodu.

U stabilnego hemodynamicznie i oddechowo noworodka z chłonkotokiem możliwe jest postępowanie wyczekujące oparte na założeniu, że większość chłonkotoków ma tendencję do samoograniczania. Proces ten zakłada utworzenie alternatywnych dróg spływu chłonki do układu żylnego i samoistnym ustąpieniu wycieku chłonki do jam ciała. Niestety, zdolność poszczególnych pacjentów do wytworzenia alternatywnego spływu chłonki do krążenia żylnego bywa zmienna i nieprzewidywalna dlatego nie można przewidzieć jak długo będzie utrzymywał się chłonkotok. Okres ten waha się najczęściej od kilku tygodni nawet do kilku miesięcy.

Odmienne działania terapeutyczne należy podjąć u noworodków i niemowląt niewydolnych krążeniowo lub 
oddechowo, u których utrzymuje się bardzo wysokie ciśnienie związane z obecnością dużej ilości chłonki w opłucnej lub otrzewnej. Wówczas konieczne jest zastosowanie drenażu. Należy jednak pamiętać, że drenaż chłonkotoku prowadzi do istotnej utraty płynów, białka, elektrolitów, tłuszczów, immunoglobulin i limfocytów (głównie limfocytów). Niestety, te straty są bardzo niebezpieczne, ponieważ doprowadzają do znacznego zaburzenia równowagi układu odpornościowego małego pacjenta, co istotnie zwiększa ryzyko rozwoju zakażenia. W takiej sytuacji konieczne jest wyrównywanie strat, podaż immunoglobulin oraz profilaktyka zakażeń.

Ponadto stosując drenaż chłonki, trzeba się liczyć z opóźnieniem procesu wytwarzania alternatywnych dróg spływu chłonki do krążenia żylnego. Jednak pomimo licznych działań niepożądanych drenaż odbarczający jest konieczny u znacznego odsetka chorych z wrodzonym chłonkotokiem opłucnowym [2, 9].

Istotny element leczenia chłonkotoku stanowi modyfikacja leczenia żywieniowego. U dzieci wydolnych krążeniowo i oddechowo, które mogą być żywione enteralnie, należy włączyć do żywienia mieszanki niskotłuszczowe zawierające średniołańcuchowe kwasy tłuszczowe (tzw. mieszanki MCT (middle chain triglycerides), które nie są transportowane z chłonką. Taka dieta w znacznym stopniu ogranicza ilość produkowanej chłonki przyspieszając ustąpienie wycieku [7, 8, 13, 15].

U dzieci wymagających respiratoroterapii, u których konieczne jest intensywne wyrównywanie strat związanych z dużym wyciekiem chłonki, oraz u tych pacjentów, u których żywienie mieszankami zawierającymi średniołańcuchowe kwasy tłuszczowe nie przyniosło pożądanego rezultatu, należy jak najszybciej wdrożyć żywienie pozajelitowe. Należy jednak przestrzegać, aby do sporządzania roztworu żywienia pozajelitowego zastosować emulsje tłuszczowe, których składowe nie są transportowane układem chłonnym.

W ostatnich latach pojawiły się doniesienia o farmakologicznym leczeniu chłonkotoku stosując somatostatynę lub jej syntetyczny analog - oktreotyd. Leki te wpływaja na zmniejszenie przepływu chłonki i można je bezpiecznie stosować nawet u noworodków.

Niestety, nie zawsze uzyskuje się zamierzony efekt terapeutyczny. Według piśmiennictwa somatostatynę i oktreotyd stosuje się u dzieci przez okres 2-4 tygodni, przy czym pierwszy z wymienionych leków - podawany jest wyłącznie dożylnie (maksymalna dobowa dawka wynosi $300 \mu \mathrm{g} / \mathrm{kg} \mathrm{mc}$.) Oktreotyd wykazujący silniejszy od somatostatyny efekt terapeutyczny i posiadający dłuższy okres półtrwania można stosować albo dożylnie (w maksymalnej dawce dobowej 250 g/kg mc.), albo podskórnie (zalecana dawka to $50 \mu \mathrm{g} / \mathrm{kg} \mathrm{mc}$./dobę). Uważa się, że obydwa leki obniżaja przepływ krwi przez naczynia trzewne, zmniejszają motoryke jelit oraz hamują działanie wielu hormonów i peptydów regulacyjnych przewodu pokarmowego.
W efekcie ich działania dochodzi do obniżenia wydzielania w przewodzie pokarmowym, wchłaniania jelitowego oraz przepływu chłonki przez naczynia chłonne jelit [7, 8, 15].

Leczenie chłonkotoku zaczynamy od drenażu, który jest wskazany w momencie potwierdzenia rozpoznania i ma na celu:

- jednoznaczne potwierdzenie laboratoryjne chłonkotoku,

- szybkie usunięcie płynu z opłucnej,

- kontrola wielkości wycieku chłonki

- uzyskanie rozprężenia się płuca.

U chorych z niewielką ilością płynu w jamie opłucnej, w szczególności jeśli jest to przesięk, nie stosuje się drenażu opłucnowego. Drenaż jest konieczny w przypadku dużych wysięków z towarzyszącymi zaburzeniami funkcji oddechowych, a zwłaszcza narastających objawów niewydolności oddechowej. Jeśli chłonkotok nadal nie ustępuje po upływie 5 tygodni leczenia farmakologicznego i żywieniowego, bądź następuje znaczne kliniczne pogorszenie stanu pacjenta, należy rozważyć leczenie chirurgiczne. Interwencje chirurgiczne mogą polegać na:

- wytworzeniu połączeń między jamami ciała,

- wykonaniu pleurodezy,

- operacyjnym podwiązaniu,

- embolizacji przewodu piersiowego.

W przypadku chłonkotoku opłucnowego można wytworzyć droge spływu chłonki z klatki piersiowej do jamy otrzewnej, implantując zestaw (np. niskociśnieniowy Codman Hakim) do drenażu komorowo-otrzewnowego. Natomiast w przypadku chłonkotoku brzusznego można zastosować drenaż otrzewnowo-żylny.

Kolejną z opcji terapeutycznych - najczęściej wykorzystywanych u dorosłych pacjentów, zwłaszcza w paliatywnym leczeniu wysięku nowotworowego - jest wykonanie pleurodezy. Wówczas po uzyskaniu pełnego rozprężenia płuca metodą drenażu opłucnej doprowadzamy do zrostu między blaszkami - trzewną i ścienną, co ostatecznie uniemożliwia gromadzenie się płynu w zarośniętej jamie. Poprzez podanie środka obliterującego do jamy opłucnej można doprowadzić do stanu zapalnego w obrębie jamy opłucnej, który doprowadza do odkładania się włóknika na jej blaszkach powodując między nimi trwały zrost. Wśród najczęściej stosowanych środków, zgodnych ze standartami ATS/ERS, jest talk w postaci proszku bądź zawiesiny - oceniany jako najskuteczniejszy - niemal 90\% skuteczności, oraz pochodne tetracykliny (głównie doksycyklina) oraz bleomycyna. Jednak część autorów rezerwuje wykonanie pleurodezy jako zabiegu uzupełniającego po operacji podwiązania przewodu piersiowego [13].

\section{Embolizacja przewodu piersiowego}

Embolizacja przewodu piersiowego polega na uwidocznieniu w limfografii zbiornika mleczu i przezskórne cewnikowanie 
przewodu piersiowego. Procedurę tę dotychczas wykonywano wyłącznie u dorosłych jednak w ostatnim czasie udało się ją zastosować także u kliku małych niemowląt [13].

\section{Chłonkotok pooperacyjny}

Chłonkotok pooperacyjny najczęściej występuje po zabiegach resekcji przełyku połączonych z rozległą dysekcją węzłów chłonnych śródpiersia (ok. 3\%). W resekcjach anatomicznych tkanki płucnej jest oceniany na około 0,4\%. Główną zasadą postępowania operacyjnego jest takie operowanie, aby nie doszło do uszkodzenia przewodu piersiowego. W przypadku konieczności rozległego wycięcia węzłów chłonnych tylnego śródpiersia poleca się rutynowe podwiązanie przewodu piersiowego. Drenaż chłonki po wycięciu całego płuca utrzymujący się ponad 7 dni jest wskazaniem do interwencji chirurgicznej celem podwiązania przewodu piersiowego. Chłonkotok po wycięciu płata płuca w zasadzie powinien być leczony zachowawczo [13].

Celem leczenia operacyjnego jest: powstrzymanie wycieku chłonki, doprowadzenie do rozprężenia się płuca oraz spowodowanie obliteracji jamy opłucnej po stronie wycieku

Wśród wielu metod postępowania chirurgicznego, którego celem jest zahamowanie wycieku chłonki, wymienia się w kolejności najczęściej stosowane:

- proste podwiązanie poniżej miejsca uszkodzenia,

- nadprzeponowe podwiązanie en mass z otaczającymi go tkankami,

- zespolenie z żyłą bezimienną,

- podanie do przewodu piersiowego środków obliterujących (kleju fibrynowego),

- odkorowanie płuca,

- decorticatio,
- wycięcie opłucnej ściennej,

- pleurectomia parietalis,

- chemiczną pleurodeze,

- opłucnowo-otrzewnowy shunt z użyciem specjalnej zastawki (double-valve Denver).

Technicznie operacyjne zamknięcia wycieku chłonki dokonuje się poprzez podwiązanie zbiornika mleczu lub przewodu piersiowego poprzez laparotomię/torakotomię, bądź laparoskopowo/torakoskopowo [13]. W leczeniu operacyjnym opisywane jest również stosowanie kleju fibrynowego [3].

\section{Podsumowanie}

Chłonkotok jest rzadkim, lecz bardzo poważnym powikłaniem rozległych zabiegów operacyjnych w obrębie klatki piersiowej (operacje wrodzonych wad serca), jak również wrodzonym problemem noworodków, lub konsekwencją procesów rozrostowych w obrębie klatki piersiowej.

W przypadku pogorszenia się stanu ogólnego dziecka po leczeniu kardiochirurgicznym z potwierdzonym w badaniach obrazowych płynem w jamie opłucnowej, obligatoryjne jest pobranie płynu nie tylko do badań mikrobiologicznych, ale również do badań laboratoryjnych, w celu ustalenia właściwego rozpoznania.

Przedłużający się wyciek chłonki prowadzi do szeregu groźnych dla życia powikłań, uruchamiając jednocześnie kaskadę reakcji i zaburzeń biochemicznych oraz immunologicznych. Obecnie podejmuje się próby farmakologicznego leczenia chłonkotoku z zastosowaniem somatostatyny lub jej analogów; ich empiryczna skuteczność w połączeniu z drenażem opłucnowym pozwala na efektywne i mniej urazowe postępowanie zachowawcze.

\section{Abstract}

Lymphorrhea is a rare but very serious complication of extensive thoracic surgery (operations for congenital heart defects), as well as congenital neonatal problem, or the consequence of proliferative processes in the chest. The paper presents the causes of lymphorrhea, diagnostic procedures as well as pharmacological and surgical treatment options. Key words: Iymphorrhea, congenital heart defects, heart surgery

Folia Cardiologica 2018; 13, 4: 359-366

\section{Piśmiennictwo}

1. Soto-Martinez M, Massie J. Chylothorax: diagnosis and management in children. Paediatr Respir Rev. 2009; 10(4): 199-207, doi: 10.1016/j.prrv.2009.06.008, indexed in Pubmed: 19879510.

2. Postek G, Werner B, Streuch H, et al. Chylothorax u noworodków. Skuteczne leczenie z zastosowaniem somatostatyny (doniesienie wstępne). Pediatr Pol. 2003; 78: 323-326.
3. Lopez-Gutierrez JC, Tovar JA. Chylothorax and chylous ascites: management and pitfalls. Semin Pediatr Surg. 2014; 23(5): 298-302, doi: 10.1053/j.sempedsurg.2014.09.011, indexed in Pubmed: 25459015.

4. François M, Caprini A, Hosking B, et al. Sox18 induces development of the lymphatic vasculature in mice. Nature. 2008; 456(7222): 643-647, doi: 10.1038/nature07391, indexed in Pubmed: 18931657. 
5. Schulte-Merker S, Sabine A, Petrova TV. Lymphatic vascular morphogenesis in development, physiology, and disease. J Cell Biol. 2011; 193(4): 607-618, doi: 10.1083/jcb.201012094, indexed in Pubmed: 21576390.

6. Alitalo K, Tammela T, Petrova TV. Lymphangiogenesis in development and human disease. Nature. 2005; 438(7070): 946-953, doi: 10.1038/nature04480, indexed in Pubmed: 16355212.

7. Widjaja A, Gratz KF, Ockenga J, et al. Octreotide for therapy of chylous ascites in yellow nail syndrome. Gastroenterology. 1999; 116(4): 1017-1018, indexed in Pubmed: 10092335.

8. Huang Qi, Jiang ZW, Jiang J, et al. Chylous ascites: treated with total parenteral nutrition and somatostatin. World J Gastroenterol. 2004; 10(17): 2588-2591, indexed in Pubmed: 15300913.

9. Bacewicz L, Stefanowicz M, Markiewicz-Kijewska M, et al. Wybrane powikłania po operacjach w klatce piersiowej u nowordków i niemowląt. Standardy Medyczna Problemy Chirurgii Dziecięcej. 2011; 1(2): 90-97.

10. Hsu HF, Chou YH, Wang CR, et al. Catheter-related superior vena cava syndrome complicated by chylothorax in a premature infant.
Chang Gung Med J. 2003; 26(10): 782-786, indexed in Pubmed: 14717215

11. Ibrahim H, Asamoah A, Krouskop RW, et al. Congenital chylothorax in neonatal thyrotoxicosis. J Perinatol. 1999; 19(1): 68-71, indexed in Pubmed: 10685206.

12. Brito T, Oliveira C, Sousa L, et al. Congenital chylothorax: a case report. Ultrasound Obstet Gynecol. 2003; 21(1): 70-71, doi: 10.1002/ /uog.17, indexed in Pubmed: 12528166.

13. Singh A. Gerbode Defect of Congenital Variety in an Infant: A Case Report. JOURNAL OF CLINICAL AND DIAGNOSTIC RESEARCH. 2016, doi: $10.7860 / \mathrm{jcdr} / 2016 / 16801.7318$.

14. Smoke A, Delegge MH. Chyle leaks: consensus on management? Nutr Clin Pract. 2008; 23(5): 529-532, doi: 10.1177/ /0884533608323424, indexed in Pubmed: 18849558.

15. Panthongviriyakul C, Bines JE. Post-operative chylothorax in children: an evidence-based management algorithm. J Paediatr Child Health. 2008; 44(12): 716-721, doi: 10.1111/j.1440-1754.2008.01412.x, indexed in Pubmed: 19077067. 